\title{
IZDEGŠANA UN GARĪGĀS VESELĪBAS PROBLĒMAS KĀ PROFESIJAS MAIN̦AS IEMESLS: BŪTISKIE APSVĒRUMI JAUNAS PROFESIJAS IZVĒLE
}

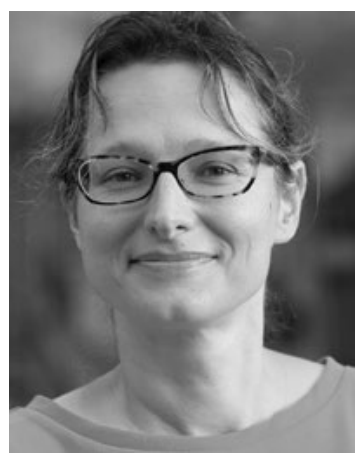

Oksana Žabko, sociālo zinātṇu mağistre sociolog̣ijā, ir nodibinājuma Baltic Institute of Social Sciences pētniece un Latvijas Universitātes Sociālo zinātņu fakultātes sociologijas doktorantūras studente. Savu profesionālo darbību veltỉjusi darba tirgus pētijumiem vairāk nekā 15 gadu garumā, citstarp pētijusi darba un privātās dzīves līdzsvarošanas iespējas, cilvēkresursu piesaistes problemātiku, strādājošo prasmju atbilstību darba tirgus vajadzībām, motivāciju un iespējas iesaistīties pieaugušo izglìtībā. Sava promocijas darba tēmu par profesijas maiņas apstāḳliem, to raksturīgākajiem modeliem un pieaugušo izglîtības piedāvājuma atbilstību šis pārmaiņas piedzīvojošo strādājošo vajadzībām izvēlējusies, sekojot mūsdienu darba tirgū novērotajām attīstības tendencēm.

Raksturvārdi: profesijas maiņa, profesionālā mobilitāte, profesijas izvēle, garīgā pārslodze, izdegšana, darba un privātās dzìves līdzsvars.

\section{Ievads}

Strādājošo garīgās veselības saglabāšana Covid-19 pandēmijas laikā ir kḷuvusi par aktuālu jautājumu', lai gan garīgās pārslodzes negatîvā ietekme uz strādājošo darba motivāciju, produktivitāti un pašnovērtējumu ir bijusi ārvalstu speciālistu redzeslokā jau ilgi pirms pandēmijas sākuma ${ }^{2}$. Tomēr Latvijā šis temats līdz šim ir bijis salīdzinoši mazaktuāls. Lai gan izdegšanas sindroms (pārslodzes radìts garīgs un fizisks izsīkums) ir iekḷauts arodslimíbu sarakstā ar 2007. gada 1. janvārỉ ${ }^{3}$, nodarbināto izdegšana lîdz šim tika atpazîta novēloti un tika ārstēta, personai individuāli vēršoties pie veselïbas aprūpes speciālistiem ${ }^{4}$. Raksturīgi, ka Latvijas iedzīvotāji pamatā izturas pret savu veselïbu kā instrumentu citu mērķu, piem., augstākas dzīves kvalitātes, sasniegšanai, nevis

\footnotetext{
1 Eurofound 2021.

2 Piem., Barthauer et al. 2020; Boersma, Lindblom 2009.

3 Ministru kabinets 2006.

4 Eurofound 2018.
}

kā tās dalıu, maz uzmanības veltot saslimšanu profilaksei ${ }^{5}$. Turklāt garīgo veselïbu stiprinošus ieradumus (piem., izvairīšanos no stresa, pietiekamu miegu) Latvijas iedzīvotāji kā sev raksturīgus atzist reti ${ }^{6}$.

Tā kā izdegšanas sindroma rašanos veicina virkne darba vides fizisko un psihologisko faktoru, piem., augsta konkurence, orientēšanās uz panākumiem, konflikti un sociālā atbalsta trūkums darbavietā, darbs ar klientiem u. tml. ${ }^{7}$, tad blakus tiešai slimības ārstěšanai profilaktisks individuāla limmeņa risinājums ir brīvprātīga darbavietas vai pat profesijas maiņa ${ }^{8}$. Ārvalstu literatūrā profesijas maiṇa parasti tiek aplūkota kā galējs un reti sastopams lēmums un analizēta caur uzkrātās pieredzes un ienākumu zaudējumu, kā arī būtisku papildu ieguldijjumu prizmu, jo iepriekš iegūtās prasmes un zināšanas nav vai ir maz

\footnotetext{
${ }^{5}$ Silis 2006.

6 Turpat.

7 Eurofound 2018.

${ }^{8}$ Hughes 2001.
} 
piemērojamas jaunajā profesijā̄ ${ }^{9}$ Lai gan kopumā ārvalstu literatūrā ir labi izpētīta izdegšanas saistība ar nodomu mainìt profesionālās darbības virzienu ${ }^{10}$, mazāk ir zināms par lēmuma pieņemšanas procesa gaitu, kura rezultātā indivīds vairāku alternatīvu risinājumu starpā par vispieņemamāko ir atzinis tieši profesijas maiṇu. Latvijas gadījumā raksta autorei nav izdevies atrast pētijumu, kurā būtu aplūkoti līdzīgi jautājumi. Tādējādi šì raksta mērḳis ir, ņemot vērā Latvijas specifisko kontekstu, kurā garīgās veselības jautājumiem tiek veltīts maz uzmanības, analizēt indivīda resursus, kas veicinājuši darba vides radītas izdegšanas vai garīga diskomforta apzināšanos, un apsvērumus, kas bija svarīgi, pien,emot lēmumu mainìt profesiju. Šo jautājumu izpēte ir veikta, balstoties uz dzīvesstāsta intervijām, kas veiktas autores promocijas darba izstrādes laikā. Intervijās dalībnieki atklāj, ka viņi mainījuši profesiju arī tādu faktoru dēl, kuri negatīvi ietekmējuši viṇu garīgo veselību.

\section{Teorētiskais ietvars: lēmuma mainìt profesiju attīstiba}

Beḷgu sociālais zinātnieks R. Esbrūks (Raoul van Esbroeck) ar kolēgiem ${ }^{11}$ apraksta karjeras lēmuma attīstības modeli (angl. dynamic model of career choice development), balstoties uz plašu jēdziena "karjera" izpratni. Karjera ir indivīda profesionālās darbības gaitas (pieredzes) kopums laikā un sociālajā telpāa ${ }^{12}$, t. i., bez sasaistes ar paaugstinājumu saņemšanu. Interpretējot šādi, jebkurš lēmums, kas rada (vai kavē) izmaiņas indivīda darba dzīvē, tiek pieņemts, sekojot piedāvātajam karjeras lēmuma attīstības modelim.

R. Esbrūka un vina kolēǵg modelis balstās uz pārliecību, ka, lai pieņemtu lēmumu par savas darba dzīves tālāko virzību, indivīds veic sešas darbības, taču tās nav sakārtojamas hierarhiskā secībā un savstarpēji neizslēdz cita citu $^{13}$. Tādējādi, lai gan modelis aptver darbības, sākot ar brīdi, kad indivīds sastopas ar

\footnotetext{
9 Sk., piem., Blau 2000.

10 Sk., piem., Barthauer et al. 2020.

11 Van Esbroeck, Tibos, Zaman 2005.

12 De Vos, Jacobs, Verbruggen 2021.

13 Van Esbroeck, Tibos, Zaman 2005.
}

kādu problēmu savā darba dzīēe vai vajadzību pieņemt lēmumu, tas paredz, ka virzỉba no vienas aktivitātes uz citu, un rezultātā veidojas izvēle, var notikt atšḳirīgā secībā. Pāriešana no vienas aktivitātes uz nākamo var notikt plūstoši, turklāt pati model̦a logika paredz arī atgriešanos un atkārtotu kādas darbības veikšanu, kamēr nepieciešamā informācija ir iegūta pietiekamā apmērā lēmuma pieņemšanai. Šìs sešas darbības ir: (1) turpmāk veicamo darbību un sagaidāmo grūtību apzināšanās; (2) savu interešu, prasmju un resursu izpēte; (3) apkārtèjās darba un organizāciju vides (iespējamo nodarbinātības veidu, profesiju un izglïtības alternatīvu) izpēte; (4) attiecību starp sevi un apkārtējo vidi izpēte, kas ietver citu iespējamo ietekmes faktoru, piem., sabiedrïbas, ekonomisko apstākḷu u. tml., apzināšanos; (5) alternatīvu skaita samazināšana iepriekš iegūtās informācijas analīzes gaitā un (6) lēmuma pieņemšana, kas ietver profesionālās tālākās virzỉbas prioritāšu sarindošanu un rīcỉbas plāna izveidošanu to sasniegšanai ${ }^{14}$. Redzams, ka šis modelis ir piemērojams, analizējot arī, kā nobriest lēmums par profesijas mainu garīgas pārslodzes dēḷ. Vispirms notiek problēmas atzišana - agrīnā stadijā tā ir apziņa, ka darba apstākḷi vairs nav pieṇemami, vēlīnākā stadijā tā ir jau piedzivota slimíbas epizode.

Analizējot interviju dalībnieku stāstijumus par profesijas maiṇu, vērā ņemamas ir vairāku citu pētijumu atziṇas. Pirmkārt, atveseḷošanās no izdegšanas sindroma var mainīt indivīda vērtību sistēmu un dzīves prioritātes ${ }^{15}$, arī piesaisti sākotnēji izvēlētajai profesijai, un rezultātā, izskatot dažādus risinājuma variantus, var tikt apsvērta pilnīga profesijas, nevis tikai darbavietas maiṇa ${ }^{16}$. Otrkārt, iziešana cauri pašizpētes, organizāciju vides izpētes un detalizēšanas stadijai un nonākšana līdz lēmumam parasti ir ilgstošs process ${ }^{17}$. Tas atkarīgs gan no indivīda sociāldemogrāfiskajām un personības iezīmēm ${ }^{18}$, gan arī no tā, vai indivīda

14 Van Esbroeck, Tibos, Zaman 2005.

15 Boštjančič, Koračin 2014.

16 Zimmerman, Swider, Arthur 2020.

17 Ruiz Castro, Van Der Heijden, Henderson 2020.

18 Carless, Arnup 2011. 
redzeslokā ir pievilcīgas nodarbinātības alternativvas ${ }^{19}$. Treškārt, sākotnējā profesijā iegūto zināšanu pārneses iespējas uz citām nozarēm atvieglo indivīda ieceri mainit profesiju ${ }^{20}$, tomēr, sastopoties ar spēcīgu iekšèju motivāciju un interesi par citām profesijām ${ }^{21}$, indivīds var veikt arī kardinālāku profesionālo pāreju, izvēloties tādu profesiju, kurā būtu nepieciešamas būtiski atškirìigas prasmes vai kurai raksturīga cita darba organizācijas kultūra.

\section{Dati un metodes}

Šajā rakstā izvirzītie pētnieciskie jautājumi ir atklāti, izmantojot kvalitatīvo pētỉjuma metodi - dzivesstāsta intervijas, kas ir nostiprinājusies pieeja Latvijas sociālajās zinātnēs gadijumos, kad pētijuma mērķis ir sniegt padzilinātu ikdienas dzīves pieredzes izpratni ilgākā laika posmā un rīcībspējas analīzi noteiktā sociālā kontekstā ${ }^{-2}$, ieskaitot slimības ietekmi uz indivīda dzīvesgājumu ${ }^{23}$. Dzīvesstāsta intervijas ir iespējams veikt dažādi ${ }^{24}$, un ši pētījuma mērķiem raksta autore formulēja galvenos jautājumus, kas ir nozīmīgi darba dzives ritējuma izpētes kontekstā, lai palīdzētu interviju dalībniekam uzsākt stāstījumu par savu sākotnējo profesiju un apstākḷiem, kas noveda pie lēmuma to mainìt. Intervijas gaitā autore uzdeva precizējošus jautājumus brīžos, kad apstājās indivīda paša veidotais stāstījums un bija nepieciešams pamudinājums to turpināt.

Zinātniskajā literatūrā pastāv tradīcija uzskatīt, ka intervētājs ir iegūto dzīvesstāstu (datu) lìdzautors, jo konkrētā indivīda dzīvesstāsts parasti šādā veidā iepriekš nav stāstìts un tā detalizētības pakāpe ir atkarīga no abu iesaistīto pušu savstarpējās mijiedarbības un komunikācijas prasmēm ${ }^{25}$. Šìs atziņas atbalsojas autores pētijumā - veikto interviju detalizētības pakāpe atšḳīrās, tāpēc interviju ilgums variēja robežās no vienas stundas un

\footnotetext{
19 Sacchi, Kriesi, Buchmann 2016.

20 Turpat.

21 Ahn, Dik, Hornback 2017.

22 Sk., piem., Bela 2018; Tetere 2015.

23 Pranka 2015.

24 Bertaux, Kohli 2008.

25 Bela-Krūmiņa 2004.
}

15 minūtēm līdz aptuveni trīs stundām, visbiežāk intervija ilga aptuveni divas stundas.

Raksta vajadzībām ir atlasīti tie promocijas darba pētījumā savāktie dzīvesstāsti (kopumā 66 intervijas), kuros atklātais profesijas maiṇas iemesls ir garīgā pārslodze darbavietā vai darba vides radītie garīgās veselības traucējumi (10 intervijas). Atlasìtajās intervijās piedalījās viens vīrietis un devinas sievietes $26-50$ gadu vecumā, interviju dalībniekiem bija augstākā vai nepabeigta augstākā izglītība.

Datu analizzes pamatā ir biogrāfiski interpretatīvā metode (angl. biographical interpretative method), kura ietver divu limenu analīzi - gan skaidri izteikto, gan slēpto (neapzināto) nozīmju atklāšanu interviju dalíbnieku dzīvesstāstos ${ }^{26}$. Šì pieeja atzīst, ka indivīdi apzinās dažādu notikumu ietekmi uz viņa profesionālo dzīvesgājumu atšksirīgi. Lai gan iegūto datu sistematizēšanai izvēlētais R. Esbrūka un kolēgu izstrādātais modelis apskata apzinātu sevis un apkārtējās vides izpētii ${ }^{27}$, kas intervijā parādītos kā skaidri izteiktas nozīmes, tomēr datu analizzes metodes izvēli noteica izvirzītie pētnieciskie jautājumi, tāpēc jāṇem vērā arī iespējamās slēptās nozīmes. Slēpto nozìmju parādīšanās sagaidāma, piem., analizējot citu faktoru ietekmi uz pien̦emto lēmumu, kā arī identificējot virzỉbu cauri karjeras lēmuma attīstîbas modeḷa aktivitātēm. Šim nolūkam tiek kodēti interviju dati, veidojot un pārbaudot pieṇēmumus par kādu dzīves notikumu savstarpējo saistību vai nozīmi, turpmākajā datu sistematizēšanas gaitā cenšoties tos integrēt un atrast savstarpējās organizācijas principus ${ }^{28}$.

\section{Garīgs diskomforts darba vidē un vajadzības to risināt apzināšanās}

Raugoties uz pagātnes notikumiem no intervijas brīža perspektīvas, stāstījums par problēmas apzināšanos caurvijas ar vispārēju indivīda refleksiju par savas sākotnēji izvēlētās profesijas un nozares darba organizācijas specifiku. Redzams, ka garīgu diskomfortu konkrētā darba vidē rada virkne faktoru, tostarp: (1) nepiemērotas profesijas izvēle, (2) ilgstošs

\footnotetext{
26 Wengraf 2001.

27 Van Esbroeck, Tibos, Zaman 2005.

28 Wengraf 2001.
} 
intensīvs darbs, (3) negatīvs organizācijas psihologiskais klimats un (4) pārāk straujš karjeras kāpums.

Nepiemērotu profesiju indivīdi ir izvēlējušies gadījumos, kad balstījušies uz vispārējiem priekšstatiem par profesiju, savu interesi par intelektuāli intensīvām vai izaicinošām studijām, maz vērības pievēršot apcerei par savu tālāko profesionālo darbību. Šeit sākotnējā karjeras lēmuma attīstîba un pieñemšana notikusi, pamatojoties uz nepietiekamiem sevis un darba vides izpētes rezultātiem. Saskaroties ar profesionālo ikdienu, interviju dalībnieki ir skaidrāk apzinājušies savas vajadzības un resursu trūkumu: Kad rezidentūrā sāku kontaktēties ar cilvēkiem, es sajutu, ka esmu intraverta, taču empātiska, ka es l̦oti izjūtu cilvēkus, un man neizdodas sevi aizsargāt no šìm sajūtām. (Sieviete, 35 gadi)

Ilgstošs intensivs darbs un tā radìts spē$\mathrm{ku}$ izsīkums ir relatīvi visbiežāk sastopamais profesijas maiṇas iemesls. Tāds darba režìms raksturīgs vairākām profesionālo pakalpojumu nozarēm. Šajā pētījumā par to stāstijja arhitektūras, grāmatvedības, reklāmas un banku sektorā nodarbinātie, biežāk tie, kas strādā darbinieku skaita ziṇā mazos uzñēmumos. Interviju dalībnieki vajadzību novērst intensīva darba radīto negatīvo ietekmi ir apzinājušies dažādi. Visbiežāk, sākoties veselības traucējumiem - bezmiegam, trauksmei, emocionālajam izsīkumam: Man sākās nervu problēmas, kā es tās saucu, jo visu laiku nesu darbu uz mājām, strādāju pa naktīm, aizmigt es nevaru... Klienti brīžiem ir apmierināti, brīžiem neapmierināti, es visu laiku tā kā jutos vainīga. [..] Es vienkāršsi emocionāli ar to visu netiku galā. Tad arī sākās emocionālās problèmas mājās, es sāku meklēt palīdzību pie [psiho] terapeita. (Sieviete, 30 gadi)

Apzināšanās notiek, parādoties nozīmīgām konkurējošām vajadzībām, kuru dēḷ nepieciešams lìdzsvarot laiku, kas veltīts darbam un privātajai: Bija l̦oti, loti daudz virsstundu, visi projekti "dega", viss bija vajadzīgs vakar, vienmēr bija neadekvāti aprēķināts laika patēriņš [darba] uzdevumam. [..] Kaut kādu laiku man tas likās .. [pieñemami], bet tad, kad es gribēju veidot nopietnākas attiecības, man tas loti traucēja. (Sieviete, 29 gadi)

Negatīvs organizācijas psihologiskais klimats rada darbiniekiem ilgstošu spriedzi, taču arī tā ietekmi interviju dalỉbnieki atpazīst novēloti, saskaroties ar nopietniem veselïbas traucējumiem: [Darbavietā bija] l̦oti daudz skaudības, l̦oti daudz aprunāšanas. [..] Es vienkārši tāpat nepatiku, vēl jo vairāk tāpēc, ka es neiesaistījos baumošanā. Es darīju savu darbu, sēdēju savā kabinetā. [..] Un tad [mans priekšnieks] uz nervu pamata saslima, [..] lìdz ar to daudzas haizivis man beidzot varēja tikt klāt. Man pašai arī sākās veselības problēmas, man vairākas reizes bija epileptiskas lēkmes. Pie dakteriem noskaidrojās, ka tas ir uz nervu pamata. [..] Es arī paralēli gāju pie psihoterapeita. Tas viss rezultējās ar to, ka es sapratu, ka man ir jāmaina mans dzīves gājums. (Sieviete, 37 gadi)

Pārāk straujš karjeras kāpums var radìt spriedzi, kura rezultējas atkarības vielu lietošanā: Es biju par jaunu priekš tā [amatu paaugstinājuma] lēciena, jo es nonācu [nākamajā lìmenī] zem valdes. Tu katru dienu nāc uz darbu šlipsē, bet pats ìstenībā esi vēl bērns. [..] Man bija par maz pieredzes. Tas pieredzes deficìts radīja iekšéju trauksmi. (Vīrietis, 37 gadi)

Kā redzams apskatītajos piemēros, problēmas apzināšanos veicina saskarsme ar realitāti - veselības problēmām vai privāti nozīmīgu citu cilvēku (parasti - dzivesbiedra) satraukumu, vērojot intervijas dalībnieka pašsajūtu pēc darba. Redzams, ka nerisināts satraukums laika gaitā uzkrājas: Es kaut kādu pusotru gadu domāju, ka tas nav .. [pieñemami], bet es neko negrasījos darìt, jo visur citur ir tāpat. [..] Tad arī strīdi ar manu dzīvesbiedru sāka palikt arvien trakāki, jo vinam bija cita attieksme pret to, kā cilvēki organizē savu laiku. (Sieviete, 29 gadi)

Problēmas apzināšanās un lēmuma pieņemšanas laikā daḷa interviju dalībnieku ir apmeklējuši psihoterapeitu. Retākos gadijumos dzīvesbiedra lēmums un piedāvātais problēmas risinājums, norādot konkrētu citu profesionālās darbības alternatīvu, ir izškikirošais: Es tiešām izdegu, jo ḷoti bieži bija darbs naktīs, es gāju mājās un raudāju. Vìrs skatījās, skatījās uz mani: "Ej prom no turienes!" Tāpēc, ka [vinam] apnika, ka es raudu. (Sieviete, 50 gadi)

Aplūkotie dzivesstāsti rāda, ka atbalstu un pamudinājumu risināt darba vidē radušos garīgo diskomfortu interviju dalïbnieki pamatā saṇēmuši ārpus savas profesionālās vides. Jautāti par atbalstu darbavietā, kopējo nostāju spilgti raksturo šāda atzīšanās: Par 
tādām lietām ar darba devēju nerunā, tas nav piennemts. Varbūt tad, kad tu jau esi izaudzis [..], tev jau ir vismaz desmit gadu pieredze un tu jau kaut kà spēj prioritizèt savu laiku. Kamēr tu esi jauns un bez savas gimenes, tev vienkārši ir jāmoči [intensīvi jāstrādā]. [..] Tā vēl aizvien notiek. (Sieviete, 30 gadi) Redzams, ka darba un privātās dzīves līdzsvars intervijas dalībnieka skatījumā ir nevis pašsaprotamas strādājošā tiesības, bet iespējas, kas rodas tikai noteiktos apstākḷos - līdz ar personības briedumu un karjeras izaugsmi, iegūstot ietekmīgu amatu. Tādējādi profesijas maiṇa ir izeja no situācijas, kurā indivīdam vienam pašam nav pietiekamu resursu aizstāvēt savas darba tiesības un rūpēties par savām vajadzībām.

\section{Savu interešu un resursu izpēte}

Kā rāda dzīvesstāsti, savu interešu un resursu izpēte un apkārtējās darba un organizācijas vides izpēte notiek savstarpējā mijiedarbībā.

Savu interešu un resursu izpētes gaitā pakāpeniski samazinās indivīda piesaiste sākotnēji izvēlētajai profesijai un atklājas jaunas profesionālās intereses. Piesaistes mazināšanās ietver savas profesijas sociālās nozìmes un vērtības pārskatī̌̌anu, uzdodot sev jautājumus, piem.: Käds ir mans pienesums cilvēcei? Ko es labu daru ar savu darbu? (Sieviete, 30 gadi)

Piesaistes mazināšanās var izpausties kā intereses trūkums turpināt strādāt ierastajā profesijā: Es sāku domāt, ka kaut kas dzīvē ir jāmaina, ka kaut kas dzìvē nav labi. Tu sāc sūtìt $C V$, notiek intervija, mès sēžam un runājam, un es saprotu, ka ne vini man kaut ko var piedāvāt, ne arī es viniem. (Sieviete, 43 gadi)

Izpētes rezultāts ir profesionālo interešu pārskatǐšana un pielāgošana, kas nozīmē no jauna atklāt, kā īstenot līdzšinējās profesionālās intereses citā veidā vai kā kādu brīvā laika aizraušanos padarìt par savu profesiju. Tas atklājas šādos pieredzes stāstos:

Es ilgi domāju, ka, no vienas puses, mani interesē psihoterapija, taču stāstus par vardarbību es nevarētu izturēt savas psihologiskās struktūras dēl, taču tāda biznesa psihologiija, kur cilvēki risina darba jautājumus, mani varētu interesēt. (Sieviete, 30 gadi)

[Pēdèjos trīs gadus] es biju sākusi staigāt pa visādiem semināriem un kursiem. Iekšējo balsi es jau biju iepriekš sajutusi. Es gāju mācīties aromterapiju, masāžas... (Sieviete, 43 gadi)

Interese par kādu profesiju var arī atklāties, saskaroties ar tajā strādājošajiem speciālistiem: Es pati gāju pie fizioterapeita, un man ar vinu bija nodibinājies labs kontakts. Man patika tas, ko vina darīja, viña man arī daudz stāstīja par savu darba dinamiku. Es sapratu, ka tas man interesē, mani saistīja cilvēka veselība, es redzēju jēgu šim darbam. (Sieviete, 30 gadi)

Resursu izpēte parasti ietver pieejamā laika un finanšu izvērtējumu, interviju dalïbniekiem apzinoties, ka jāapgūst jaunajai profesijai specifiskas zināšanas un prasmes. Tā kā interviju dalībnieki ir mainījuši profesiju pēc vairāku vai pat daudzu gadu darba citā jomā, jaunas profesijas apguve (izglìtības iegūšana) tiek uztverta atškikirīgāk nekā jaunībā. Salīdzinoši rūpīgi tiek izvērtēts profesijas apguvei pieejamais brīvais laiks un iespējas izturēt intensīvu intelektuālo (garīgo) slodzi. Tāpēc, lai iegūtu papildu laiku, kā risinājums tiek apsvērta iespēja nestrādāt, kas secīgi noved pie jautājuma par sagaidāmo ienākumu samazinājumu un vajadzības sabalansēt ğimenes budžetu. Redzams, ka profesijas maina bija iespējama gadijumos, kad interviju dalïbniekiem bija pieejami brīvi finanšu resursi - iekrājumi, dzīvesbiedra un vecāku atbalsts vai bankas aizñēmums: Man sakārtojās viens gimenes īpašums, kas nesa naudu. Pēkšnni radās nauda. [..] Pēkšñi pavērās tā iespēja, ka tu neesi vairāk atkarīgs no darba, tu vari pat [ïstenot] to savu kecerīgo domu, kur tu [ap]skaudi, ka [..] mācīsies... (Vīrietis, 37 gadi); Ja man nebūtu bijuši uzkrājumi, tad es to nebūtu varējusi izdarìt. (Sieviete, 43 gadi)

\section{Apkārtējās darba un organizāciju vides izpēte}

Apzinoties, ka darba vide rada garīgu diskomfortu, daļa interviju dalībnieku atzīst, ka sākotnēji viniiem trūcis ideju, kā risināt šo problēmu. Raksturīgi, ka iesākumā viens no mēginājumiem ir saglabāt profesiju, bet mainīt darbavietu, pārejot uz citu nozares uzñēmumu. Tā darba kultūra bija vērsta uz... [izdegšanu]. [..] Es izlèmu, ka es iešu prom no darba, bet man nebija ideju, ko es tālāk darī̌su, es [tikai] sapratu, ka es vairs nevaru. (Sieviete, 36 gadi) Darbavietu maiṇa l̦auj iegūt plašāku 
priekšstatu par darba organizāciju nozarē, salīdzināt darba devēju prasības un darba apstākḷus, iegūstot laiku pārdomām un arī savu interešu pārskatīšanai.

Citos gadijumos darba un organizācijas vides izpēte ir daḷa no problēmas apzināšanās, kuru veicina arī dažādu nozaru darba organizācijas un kultūras salīdzinājums, daloties pieredzē draugu un paziṇu lokā. Tà rezultātā, piem., kāda intervijas dalībniece secināja, ka citas nozares uzṇēmumos raksturīgi tādi darba apstākḷi, kādi nav atrodami viņas pārstāvētajā profesijā: .. ir veselības apdrošināšana, nekad nav virsstundas, brīvdienās nav jāstrādā, neviens uz tevi nekad īpaši nedusmojas, viss tiek labi saplānots un visi ir saprotoši. (Sieviete, 29 gadi)

Lai gan aplūkotajā piemērā atklājas, ka labākas sociālās garantijas, darba un privātās dzīves lïdzsvarošanas iespējas un pozitiva saskarsmes pieredze darbavietā ir faktori, kurus citas profesijas meklējumu laikā ir izskatījuši interviju dalībnieki, tomēr citos dzīvesstāstos atklājas interese par pretējo, proti, profesiju vai nodarbinātības formu, kurai raksturīga zemākas sociālās garantijas un aizsardzība (piem., pašnodarbinātā statuss), taču tā atbilst intervijas dalībnieka jaunatklātajām profesionālajām interesēm.

Vides izpētes gaitā tiek apzinātas arī obligāto profesionālo prasmju attīstības un, ja nepieciešams, izglītības iegūšanas iespējas. Šajā procesā, kā redzams intervijās, tiek meklēts visvienkāršākais veids, kas prasa vismazāk resursu. Iespēju meklējumi mijiedarbojas ar daudzveidīgajām indivīda darba, izglītošanās un privātās dzìves vajadzībām, sociālajām normām un vērtībām: Man vajag, lai man papìros ir kārtība. Varētu jau strādāt tirgū tikai ar kursiem, loti daudzi tā strādā, tā arī var... Es tādu iespēju vispār neizskatīju. Kaut gan tagad man liekas... Tagad, kad tu to visu zini, tad liekas, ka var visu ko citādāk, bet patiesībā jau $n \bar{e}$, tāpat bija jāiet jāmācās. (Sieviete, 43 gadi)

\section{Detalizēšana, lēmuma pieṇemšana un pārskatǐšana}

Daudzās intervijas parāda, ka lēmums tiek pieṇemts ilgākā laika posmā, parasti interviju dalïbnieki min gadu vai pusotru gadu ilgu pārdomu, meklējumu, pašizpētes un vides izpētes posmu, kura rezultātā nonākuši pie lēmuma mainīt profesiju. Dzivesstāstos atklājas, ka situācijā, kad garīgais izsīkums vai veselības problēmas bijušas mazāk izteiktas, indivīds biežāk šaubās, vai profesijas maiṇa ir pareizais risinājums. Ilustrācijai piedāvātais dzīvesstāsts: Es visu laiku [svārstījos] uz priekšu un atpakal, labi, es nokārtošu biologíiju [centralizèto eksāmenu, kas nepieciešams, lai iestātos], tas par sliktu man nenāks. Nokārtoju, arī vēl šaubījos stāties, nestāties. [..] Viena lieta, kas mani spēecìgi turēja atpakal, bija tas, ka man likās, ka es tik daudz esmu ieguldījusi šajā [pirmajā] profesijā. Visa izglìtība, visa pieredze, viss tas, kam es esmu gājusi cauri... Kā es tā vienkārši visu pametǐšu? Otra lieta - šaubas par nākotni, jo es nezināju vai [izvēelètais jaunais studiju virziens] būs mans, vai es ar to varēšu nopelnìt iztiku, ko es tālāk darī̌su. Man tas nebija skaidrs [..], bija tāda liela nedrošiba. Es pat tagad brīnos, kur man bija tāda drosme tādu risku uznemties. (Sieviete, 36 gadi)

Bieži dzīvesstāstā intervijas dalībnieks koncentrējas uz jau îstenotās izvēles sīkāku izklāstu un pamatojumu, sniedzot samērā īsu pārskatu par tiem risinājuma variantiem, kuri lēmuma pieņemšanas procesā tika atmesti. Intervijās būtiskākais atklājums ir sākotnējais lēmuma pieņemšanas process un lēmuma pielāgošana savām interesēm. Abi šie procesi ilustrē belǵgu zinātnieka R. Esbrūka un kolẹgu izstrādātā modẹ̦a darbību. Kā piemēri šeit minamas situācijas, kad indivīdi ir sākotnēji izvēēejušies ilgāku ceḷu, kā mainīt profesiju, piem., iegūt augstāka līmeņa izglìtību, kura prasa vairāk laika un kurai nepieciešami lielāki resursi, laika gaitā atklājot, ka mērkịi ir iespējams sasniegt vienkāršāk: Es zināju, ka vēlos darìt kaut ko saistībà ar cilvēka veselību [..]. Pirmā doma bija [kḷūt] par diētas àrsti un palīdzēt citām sievietēm nenokḷūt tādā [dalībniecei lìdzìgā] situācijā. [..] Es nomācījos gadu Medicinas fakultātēe, tas režìms bija traks. Es sapratu, ka tas ir biškīt par traku, jo kopsummā man desmit gadus ir jāpavada tādā režìmā. [..] Tolaik es pamanìju programmu .. [esošo specialitāti], un es pārgāju uz Rehabilitācijas fakultāti. (Sieviete, 37 gadi)

Mācības bija pirmais solis, lai tiktu tajā darbā. Lìdz ar to es beigās pañēmu akadèmisko gadu. Nav tā, ka man l̦oti to vajag, jo reti kurā 
[̌̌is nozares] darbā prasa diplomu. [..] Man bija svarīgi, lai man [pieredze] ir pēc iespējas àtrāk, lai man ir pēc iespējas mazāk problēmas. (Sieviete, 29 gadi)

Pieñemtā lēmuma pārskatīšana var notikt arī darba meklēšanas gaitā, sastopoties ar darba tirgus piedāvājumu un vairākiem izvēlētās jaunās profesijas variantiem. Dzīvesstāsti rāda, ka katra darba piedāvājuma izskatīšana prasa atkārtotu savu interešu un resursu, kā arī darba organizācijas vides izpēti, apzināšanos un pārvērtēšanu. Šajā atkārtotajā procesā var rasties tādas vajadzības, kas iepriekš uz aktuālāku vajadzību (garīga diskomforta novēršanas) fona netika apzinātas.

\section{Secinājumi}

Profesijas maiṇu piedzīvojušo interviju dalỉbnieku dzivesstāsti atklāj, ka viņu darbavietā trūkusi savlaicīga tādu darba vides faktoru novēršana, kas var veicināt strādājošo garīgu izsīkumu vai izdegšanu. Profesijas maiņa šeit parādās kā ilgākā laika posmā apsvērts risinājums situācijā, kad interviju dalībnieki vairs nav redzējuši citu iespēju, kā nodrošināt savu vajadzību pēc līdzsvarotāka laika, kas veltīts darbam un privātajai dzīvei. Redzams, ka intensīvs darbs vairākās profesionālās darbības nozarēs tiek aplūkots kā norma, tāpēc savu interešu aizstāvēšana tiek uztverta drīzāk kā normas pārkāpums, nevis kā likumiskas strādājošo tiesības.

R. Esbrūka un kolēgu aprakstītais karjeras lēmuma attīstības modelis, kas tika lietots, lai analizētu dzìvesstāstu intervijās iegūto materiālu, ḷauj pietiekami izvērsti aplūkot šādas lēmuma attīstības stadijas: vajadzības risināt problēmas aktualizēšanos, savu interešu un resursu izpēti, apkārtējās darba un organizāciju vides izpēti un lēmuma pieņemšanu. Dal̦ēji slēpta paliek alternatīvu skaita samazināšanas aktivitāte iepriekš iegūtās informācijas analīzes gaitā. Atšķirīga detalizētība ir datiem, kas ļauj noteikt visu minēto procesu atkārtošanos, sastopoties ar jaunu, aktualizētu informāciju par savām vajadzībām vai apkārtējās vides prasībām.

Būtiski, ka pētījumā atklājās jēgpilnu karjeras konsultāciju trūkums jauniešiem pirms studiju uzsākšanas (aptuveni pirms desmit vai piecpadsmit gadiem, kad studijas augstskolā uzsāka minētie interviju dalībnieki), tāpēc daḷa interviju dalībnieku, uzsākot darbu apgūtajā profesijā, izjuta trauksmi, jo psihologiski nebija piemēroti noteiktu profesionālo pienākumu veikšanai. Redzams, ka darba gaitu uzsākšana veicina interviju dalībnieku interešu, prasmju, resursu un vajadzību apzināšanos, kā arī informācijas ieguvi par citu nozaru darba vidi, uzklausot draugus (un citus tuvus cilvēkus) par profesionālās darbỉbas pieredzi.

\section{VĒRES}

Ahn, J.; Dik, B. J.; Hornback, R. (2017) The experience of career change driven by a sense of calling: An Interpretative Phenomenological Analysis approach. Journal of Vocational Behavior, 102, 48-62. doi. org/10.1016/j.jvb.2017.07.003.

Barthauer, L.; Kaucher, P.; Spurk, D.; Kauffeld, S. (2020) Burnout and career (un)sustainability: Looking into the Blackbox of burnout triggered career turnover intentions. Journal of Vocational Behavior, 117. doi. org/10.1016/j.jvb.2019.103334.

Bela, B. (2018) Nabadzības strupceḷ̌s: grūtību akumulācija un risinājumu meklējumi sieviešu pieredzes stāstos. Bela, B. (ed.) Ilgtspējīga attīstība un sociālās inovācijas. Rīga : LU Akadēmiskais apgāds, 140-166.

Bela-Krūmiņa, B. (2004) Dzīvesstāsti kā sociāli vēstījumi. Promocijas darbs. Rīga : Latvijas Universitāte.

Bertaux, D.; Kohli, M. (2008) The life story approach: a continental view. Harrison, B. (ed.) Life Story Research, I. London : Sage Publications, 42-65.

Blau, G. (2000) Job, organizational, and professional context antecedents as predictors of intent for interrole work transitions. Journal of Vocational Behavior, 56, 330-345. doi.org/10.1006/jvbe.1999.1718.

Boersma, K.; Karin Lindblom (2009) Stability and change in burnout profiles over time: A prospective study in the working population. Work \& Stress, 23, 3, 264-283. doi.org/10.1080/02678370903265860.

Boštjančič, E.; Koračin, N. (2014) Returning to work after suffering from burnout syndrome: Perceived changes in personality, views, values, and behaviors connected with work. Psihologija, 47, 1, $131-147$. Pieejams: http://www.doiserbia.nb.rs/img/doi/0048-5705/2014/0048-57051401131B.pdf (12.05.2021.). 
Carless, S. A.; Arnup, J. L. (2011) A longitudinal study of the determinants and outcomes of career change. Journal of Vocational Behavior, 78, 1, 80-91. doi.org/10.1016/j.jvb.2010.09.002.

De Vos, A.; Jacobs, S.; Verbruggen, M. (2021) Career transitions and employability. Journal of Vocational Behavior, 126. doi.org/10.1016/j.jvb.2020.103475.

Eurofound (2018) Burnout in the workplace: A review of data and policy responses in the EU. Luxembourg: Publications Office of the European Union.

Eurofound (2021) COVID-19: Implications for employment and working life, COVID-19 series. Luxembourg : Publications Office of the European Union.

Hughes, R. E. (2001) Deciding to leave but staying: teacher burnout, precursors and turnover. The International Journal of Human Resource Management, 12, 2, 288-298. doi.org/10.1080/713769610.

Ministru kabinets (2006) Arodslimību izmeklēšanas un uzskaites kārtība: Ministru kabineta noteikumi Nr. 908 (06.11.2006.). Pieejams: https://likumi.lv/ta/id/147550-arodslimibu-izmeklesanas-un-uzskaiteskartiba (12.05.2021.).

Pranka, M. (2015) Biogrāfiskā pieeja biogräfiskā pārrāruma individuālo un sociālo aspektu analīzē. Promocijas darbs. Rìga : Rīgas Stradiņa universitāte.

Ruiz Castro, M.; Van Der Heijden, B., Henderson, E. L. (2020) Catalysts in career transitions: Academic researchers transitioning into sustainable careers in data science. Journal of Vocational Behavior, 122. doi.org/10.1016/j.jvb.2020.103479.

Sacchi, S.; Kriesi, I.; Buchmann, M. (2016) Occupational mobility chains and the role of job opportunities for upward, lateral and downward mobility in Switzerland. Research in Social Stratification and Mobility, 44. doi.org/10.1016/j.rssm.2015.12.001.

Sīlis, V. (2006) Rūpes par veselību un dzīves kvalitāte. Bela, B.; Tisenkopfs, T. (sast.) Dzīves kvalitāte Latvijā. Rìga : Zinātne, 179-216.

Tetere, A. (2015) Vardarbības pārvarēšanas pieredze sieviešu dzīvesstāstos. Latvijas Universitātes Raksti / Acta Universitatas Latviensis, Sociologija/Sociology, 808, 102-114.

Van Esbroeck, R.; Tibos, K.; Zaman, M. (2005) A Dynamic Model of Career Choice Development. International Journal for Educational and Vocational Guidance, 5, 1, 5-18. doi.org/10.1007/s10775-005-2122-7.

Wengraf, T. (2001) Qualitative research interviewing: Biographic narrative and semi-structured methods. London : Sage Publications.

Zimmerman, R. D.; Swider, B. W.; Arthur, J. B. (2020) Does turnover destination matter?: Differentiating antecedents of occupational change versus organizational change. Journal of Vocational Behavior, 121. doi.org/10.1016/j.jvb.2020.103470. 